九州大学学術情報リポジトリ

Kyushu University Institutional Repository

\title{
A Study on Fire Characteristic of Cork Oaks for Forest Fire Identification in Korea
}

PARK, Young-Ju

Dept. of Fire \& Emergency Management, Kangwon National University | Laboratory of Forest

Resources Management, Division of Forest Environmental Sciences, Department of Agro-

Environmental Sciences, Faculty of Agriculture, Kyushu University

\section{LEE, Si-Young}

Professional Graduate School of Disaster Prevention, Kangwon National University | Laboratory of Forest Resources Management, Division of Forest Environmental Sciences, Department of AgroEnvironmental Sciences, Faculty of Agriculture, Kyushu University

OHGA, Shoj i

Laboratory of Forest Resources Management, Division of Forest Environmental Sciences,

Department of Agro-Environmental Sciences, Faculty of Agriculture, Kyushu University

https://doi.org/10.5109/1955392

出版情報：九州大学大学院農学研究院紀要. 63 (2)，pp. 259-264，2018-09-01. Faculty of Agriculture, Kyushu University

バージョン：

権利関係: 


\title{
A Study on Fire Characteristic of Cork Oaks for Forest Fire Identification in Korea
}

\author{
Young-Ju PARK ${ }^{1}$, Si-Young LEE ${ }^{2 *}$ and Shoji OHGA \\ Laboratory of Forest Resources Management, Division of Forest Environmental Sciences, \\ Department of Agro-Environmental Sciences, Faculty of Agriculture, \\ Kyushu University, Fukuoka 811-2415, Japan \\ (Received May 1, 2018 and accepted May 8, 2018)
}

\begin{abstract}
This study conducted an analysis of fire load of forest fuels to predict forest fire intensity and forest fire behavior. Fifth-grade cork oaks were selected for analyzing fire load. After measuring amounts of biomass, total weight found $428.9 \mathrm{~kg}$, branch parts was $57.93 \mathrm{wt} . \%$, and weight percentage was $42.07 \mathrm{wt} . \%$. Branch parts $\left(248.4 \mathrm{~kg}\right.$ ) emitted heats as $324,390.0 \mathrm{MJ} / \mathrm{m}^{2}$ and stem parts $(180.4 \mathrm{~kg})$ generated heats as $2,720,432.2 \mathrm{MJ} / \mathrm{m}^{2}$ based on the assumption that burning efficiency sets to $100 \%$, branch parts emitted 1.84 times higher heat amounts than stem parts and total heat release of cork oaks turned out 596,433.2 MJ/ $\mathrm{m}^{2}$. For total smoke release, branch parts emitted 1.36 times more smoke than stem parts and total smoke release was reported to emit $1,044,128.6 \mathrm{~m}^{2} / \mathrm{m}^{2}$. In addition, total carbon dioxide release of fifth-age class cork oaks was $865.3 \mathrm{~kg}$ and total emissions of carbon monoxide found $39.7 \mathrm{~kg}$.
\end{abstract}

Key words: Cork oaks, Forest fire identification, Biomass, Carbon monoxide, Carbon dioxide, Cone calorimeter, Ignition temperature

\section{INTRODUCTION}

Countries actively conduct research and development by quantifying absorption and emission of Carbon dioxide $\left(\mathrm{CO}_{2}\right)$ and Non-carbon dioxide(non $\mathrm{CO}_{2}$ ) generated by forest disturbance including forest fire and forest degradation not to be economically retarded after the Kyoto Protocol was released. In response to this global trend, the Ministry of Forest in South Korea released forest comprehensive measures for responding to the climate change and research on the establishment of forest carbon emission right transaction basis in Green Trading and management of Post-2012 forest absorption resources and launch Certificated Emissions Reduction for forestation business are underway(Korea 2008 ; IPPC 2003).

However, basic research to estimate and evaluate carbon dioxide and non carbon dioxide directly emitted by forest fire in quantitatively and scientifically has not been carried out. Korean territory is calculated as $100,033 \mathrm{~km}^{2}$ and forests accounts for nearly $63.67 \%$ reaching $63,688.43 \mathrm{~km}^{2}$ (Korea 2011). Due to geographical conditions, forest fire frequently occurs. In average, 478 fires have occurred over the past decade from 2001 to 2010(Korea 2011; Yim K. G 2007). Therefore, practical quantitative measures of carbon emission are needed from performing a burning experiment applied with Korean forest plants in order to estimate greenhouse gas emissions caused by forest fire(KOREA 2008).

Fire intensity of forest fire and forest fire behavior

${ }^{1}$ Dept. of Fire \& Emergency Management, Kangwon National University, Samcheok-Si, Gangwon-Do 245-711, Republic of Korea

2 Professional Graduate School of Disaster Prevention, Kangwon National University, Samcheok-Si, Gangwon-Do 245-711, Republic of Korea

* Corresponding Author (E-mail:lsy925@kangwon.ac.kr) risk system marks four artificial forest fire index that helps fire control activity plans and dangerous routes by providing fire occurrence index by lighting, burning index, and burning quantity index (Lee S. Y., 2004). Furthermore, BEHAV program developed to predict the burning risk of surface fire fuel and forest fire spread defined fire intensity as generated heat release per unit area $\left(\mathrm{Btu} / \mathrm{ft}^{2}\right)$ and presents how to quantify it. To predict these risk in case of forest fire, an investigations should be conducted to analyze forest fire-related factors including plants, geography and climate, accumulate basic documents through indoor and outdoor experiments, and establish the scientific and systematic forest fire management (Lee et al., 2001). Forest territories in South Korea are estimated to $6,368,643$ ha and broad-leaved trees accounts for nearly $27 \%$ amounting to 1718916 ha (Korea 2011). In general, broad-leaved trees are excellent for fire-resistance than needle-shaped trees. Vulnerability to forest fire or strong difference is caused by ignition temperature of leaves(Kang et al., 2002).

Therefore, this study aims to measure amounts of biomass among cork oak, which is the representative oak tree in Korea among broad-leaved trees and analyze fire load of species needed for predict forest fire intensity and forest fire behavior by performing burning experiment. Moreover, it aims to estimate amounts of carbon emission from each tree in case of forest fire by measuring actual amounts of carbon emission.

\section{RESEARCH CONTENT AND METHOD}

\section{Experiment and selecting of fuels}

A burning experiment to analyze fire load used the cone calorimeter (ISO 2002) and Ignition Temperature tester (Hong et al., 1992). Cork oak was selected for fuel known as fire resist species. fifth-age class (41-50-yearold) trees were pricked in Samcheok, Gangwon-do 
where forest fire frequently occurs in accordance with grade (first to fifth-age class). Trees were collected in April the following day after five sunny days. Original fuels were adopted to apply identical fuel forms and conditions in case of forest fire. Specific experimental conditions are presented in Table 1 and 2.

\section{Analysis of amounts of biomass}

Conducting burning experiment, biomass amounts of cork oaks were measured and weights of branch and stem parts as crown fire and subject fuels were drawn through steps presented in Fig. 1. The climate in Korea is characterized by cold and dry weather in winter and intensive rainfall in summer that features the temperate monsoon region. cork oak is a broad-leaved tree that falls leaves during winter in a temperate region. Thus, green

Table 1. Experimental conditions of cone calorimeter

\begin{tabular}{lc}
\hline \multicolumn{1}{c}{ Items } & Contents \\
\hline Size $(\mathrm{mm})$ & $100 \times 100$ \\
Weight $(\mathrm{g})$ & 50 \\
Heat flux $\left(\mathrm{kW} / \mathrm{m}^{2}\right)$ & 50
\end{tabular}

Test time (s) Time until there was no more weight decrease Material condition

Raw

Table 2. Experimental conditions of ignition temperature

\begin{tabular}{lc}
\hline \multicolumn{1}{c}{ Items } & Contents \\
\hline Model & KRS-RG-9000 \\
Method of measurement & Group type \\
Weight (mg) & 20 \\
Condition of material & Raw \\
Waiting time of Ignition (s) & 4 \\
\hline
\end{tabular}

leaves were excluded from the measurement of biomass amounts. Results of biomass amounts by parts were applied in an analysis of carbon emission and mean values from three experiments were used.

\section{Measurement of the percentage of moisture con- tent}

The measurement of green moisture contents of fuels followed ASTM D 2016 (American Society for Testing and Material) [5] and weight was measured by quantifying $200 \mathrm{~g}$, drying them on a drier with $105^{\circ} \mathrm{C}$ until no weight variation was identified every four hour. Mean values from three measurements were used.

\section{Analysis of fire characteristics}

An analysis of fire load applied outcomes from total heat release of cork oaks. Before analyzing total heat release, it measured total biomass amounts of cork oaks. Fire load was drawn by applying total heat release outcomes obtained from the experiment on total biomass amounts. Moreover, this study analyzed the characteristics of ignition at the beginning of burning as well as vulnerability caused by smoke release since release heats vary according to the characteristics of ignition at the beginning of burning while burning.

\section{Analysis of carbon emission amounts}

We used the Cone Calorimeter to conduct an analysis of carbon emission amounts (Lee et al., 2001). Specific experimental conditions are presented in Table 1 and the experiment ended when weight variation is no longer identified. Results were used as mean value obtained from three experiments. Based on the assumption that burning efficiency is $100 \%$, carbon dioxide and carbon monoxide emissions on $50 \mathrm{~g}$ weight by parts were analyzed and total emissions of carbon dioxide and carbon monoxide on biomass amounts of cork oaks were drawn by applying biomass amounts.

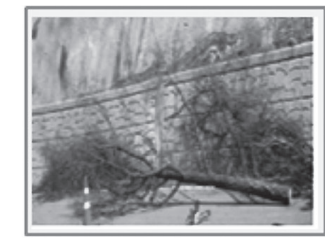

sampling

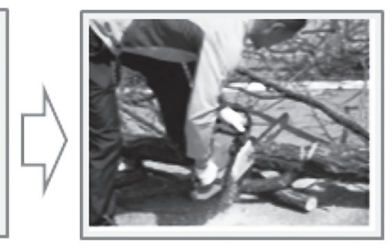

cutting

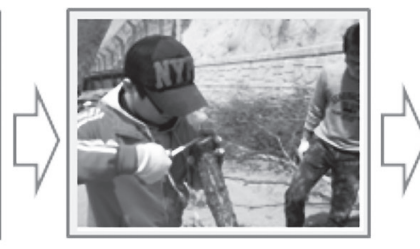

diameter measuring ( I )

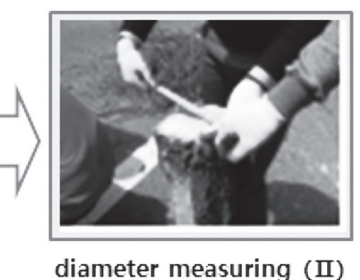

diameter measuring (II)

(1) Sample cutting and diameter measuring

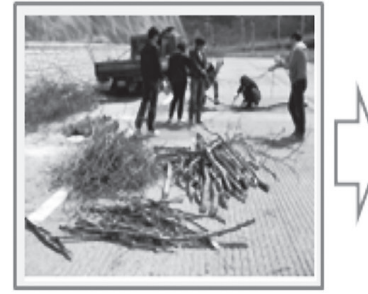

classifying ( I )

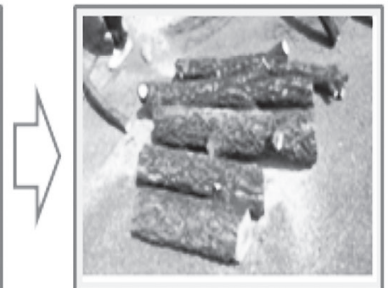

classifying (II)

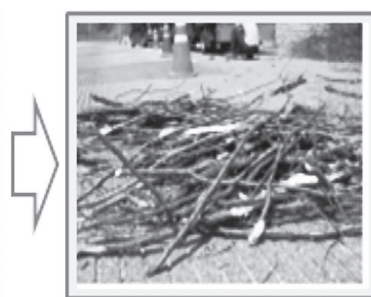

classifying (III)

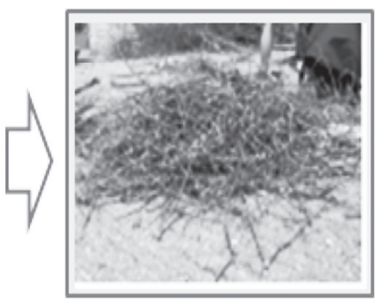

classifying (IV)

Fig. 1. Measurement of biomass amounts of cork oaks. 


\section{RESULTS AND DISCUSSION}

\section{Characteristics of the percentage of moisture content}

Percentages of moisture contents in branch and stem parts were presented in Table 3. The percentage of moisture content in April when forest fire frequently occurs ranged between $42.62 \%$ and $49.84 \%$, the result showed that the difference by parts was not significant.

\section{Characteristics of Biomass Amounts}

Biomass amounts by parts are shown in Figure 2. Mean diameter $1.78 \mathrm{~cm}$ was $38.70 \mathrm{~kg}$, weight ratio turned out 9.03 wt.\%, and $2.42 \mathrm{~cm}$ turned out $85.20 \mathrm{~kg}$. Weight ratio was found 19.87 wt.\%, $5.64 \mathrm{~cm}$ was $124.50 \mathrm{~kg}$, and weight ratio was estimated as $29.03 \mathrm{wt} \%$. In short, branch parts turned out $248.40 \mathrm{~kg}$ with 57.93 wt.\%. Stem parts was $180.4 \mathrm{~kg}$ and weight ratio turned out 42.07 wt.\%. Weight ratio of Branch parts therefore showed $8 \%$ higher than branch parts. Table 4 shows quantitative values.

\section{Characteristics of carbon emission amounts}

Regarding emission amounts of carbon dioxide,

Table 3. Percentage of Moisture Contents by Parts of Cork Oaks

\begin{tabular}{clc}
\hline \multicolumn{1}{c}{ Cork oaks } & \multicolumn{1}{c}{$\begin{array}{c}\text { Percentage of } \\
\text { moisture contents(\%) }\end{array}$} \\
\hline \multirow{5}{*}{ Branch } & $\begin{array}{l}\text { Diameter Less than } 2.10 \mathrm{~cm} \\
\text { (Mean diameter } 1.78 \mathrm{~cm} \text { ) }\end{array}$ & 49.84 \\
& $\begin{array}{l}\text { Diameter } 2.10 \sim 4.00 \mathrm{~cm} \\
\text { (Mean diameter } 2.42 \mathrm{~cm} \text { ) }\end{array}$ & 46.45 \\
& $\begin{array}{l}\text { Diameter } 4.10 \sim 8.00 \mathrm{~cm} \\
\text { (Mean diameter } 5.64 \mathrm{~cm} \text { ) }\end{array}$ & 42.62 \\
Stem & $\begin{array}{l}\text { Diameter over } 8.00 \mathrm{~cm} \\
\text { (Mean diameter } 17.30 \mathrm{~cm} \text { ) }\end{array}$
\end{tabular}

branch parts emitted $489.90 \mathrm{~kg}$ and branch parts emitted $375.37 \mathrm{~kg}$. For emissions of carbon monoxide, branch parts generated $2.20 \mathrm{~kg}$ and stem parts emitted $17.46 \mathrm{~kg}$. Therefore, this result found that branch parts emitted 1.7 times more carbons than stem parts. Total carbon dioxide emissions by cork oak species turned out 865.28 $\mathrm{kg}$ and carbon monoxide emissions found $39.68 \mathrm{~kg}$. Specific information is shown in Table 5.

\section{Characteristics of ignition}

The characteristics of ignition by parts of cork oaks are shown in Table 6 . Ignition temperature by parts ranged between $490^{\circ} \mathrm{C}$ and $550^{\circ} \mathrm{C}$ that showed the temperature difference. Observing ignition time, branch parts showed 24 seconds, which was the fastest; whereas, $1.78 \mathrm{~cm}$ twigs in average showed 175 seconds, which was the longest flaming ignition time. Faster flaming ignition proceeded in stem parts due to relatively low percentage of moisture contents and flaming ignition temperature. Ignition risk is assumed to be relatively higher than branch parts in case of forest fire. However, thick branches with $5.64 \mathrm{~cm}$ in average were flamed at 664 seconds after igniting at 86 seconds, which lasted relatively longer for burning. Twigs were flamed at $592 \mathrm{sec}-$ onds after igniting at 175 seconds, which continued burning for 417 seconds and showed relatively shorter burning time. Therefore, it was revealed that ignition risk at the beginning of burning in stem parts is relatively higher

Table 4. Analysis of Biomass Amounts by Parts of Cork Oaks

\begin{tabular}{cccc}
\hline \multicolumn{2}{c}{$\begin{array}{c}\text { Mean diameter by } \\
\text { parts }(\mathrm{cm})\end{array}$} & $\begin{array}{c}\text { Weight } \\
(\mathrm{kg})\end{array}$ & $\begin{array}{c}\text { Weight ratio } \\
(\%)\end{array}$ \\
\hline \multirow{2}{*}{ Branch } & 1.78 & 38.70 & 9.03 \\
& 2.42 & 85.20 & 19.87 \\
\multirow{2}{*}{ Stem } & 5.64 & 124.50 & 29.03 \\
& 17.30 & 180.40 & 42.07 \\
\hline \multicolumn{2}{c}{ Total weight } & 428.80 & 100.00
\end{tabular}

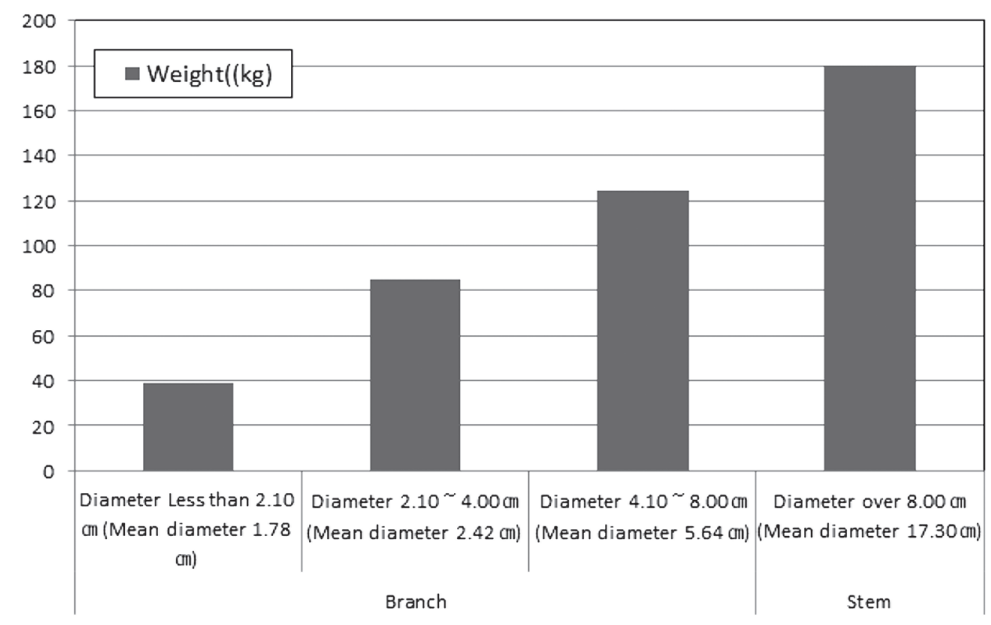

Fig. 2. Biomass amounts by parts of Cork oaks. 
Table 5. Analysis of Carbon Emissions of Cork oaks

\begin{tabular}{|c|c|c|c|c|c|}
\hline \multicolumn{2}{|c|}{$\begin{array}{l}\text { Mean diameter by parts } \\
(\mathrm{cm})\end{array}$} & \multicolumn{2}{|c|}{ Weight (kg) } & \multirow{2}{*}{$\frac{\mathrm{CO}(\mathrm{kg})}{0.04}$} & \multirow{2}{*}{$\frac{\mathrm{CO}_{2}(\mathrm{~kg})}{0.96}$} \\
\hline \multirow{6}{*}{ Branch } & \multirow{2}{*}{1.78} & Burning weight & 0.05 & & \\
\hline & & Biomass amounts & 38.70 & 3.10 & 74.42 \\
\hline & \multirow{2}{*}{2.42} & Burning weight & 0.05 & 0.05 & 0.98 \\
\hline & & Biomass amounts & 85.20 & 8.26 & 166.91 \\
\hline & \multirow{2}{*}{5.64} & Burning weight & 0.05 & 0.04 & 0.10 \\
\hline & & Biomass amounts & 124.50 & 10.87 & 248.59 \\
\hline \multirow{2}{*}{ Stem } & \multirow{2}{*}{17.30} & Burning weight & 0.05 & 0.05 & 0.10 \\
\hline & & Biomass amounts & 180.40 & 17.46 & 375.37 \\
\hline \multicolumn{2}{|c|}{ Biomass amounts } & Total biomass amounts & 428.80 & 39.68 & 865.28 \\
\hline
\end{tabular}

Table 6. Characteristics of Ignition by Part of Cork Oaks

\begin{tabular}{|c|c|c|c|c|c|}
\hline & Cork oak & $\begin{array}{c}\text { Percentage of } \\
\text { moisture contents } \\
(\%)\end{array}$ & $\begin{array}{c}\text { Ignition } \\
\text { temperature } \\
\left({ }^{\circ} \mathrm{C}\right)\end{array}$ & $\begin{array}{l}\text { Ignition } \\
\text { time } \\
\text { (sec) }\end{array}$ & $\begin{array}{c}\text { Anti-inflammation } \\
\text { time } \\
\text { (sec) }\end{array}$ \\
\hline \multirow{2}{*}{ Branch } & $\begin{array}{l}\text { Twig(Average } \\
\text { diameter } 1.78 \mathrm{~cm} \text { ) }\end{array}$ & 49.84 & 549 & 175 & 592 \\
\hline & $\begin{array}{l}\text { Thick } \\
\text { branch(Average } \\
\text { diameter } 5.64 \mathrm{~cm} \text { ) }\end{array}$ & 42.62 & 498 & 86 & 664 \\
\hline
\end{tabular}

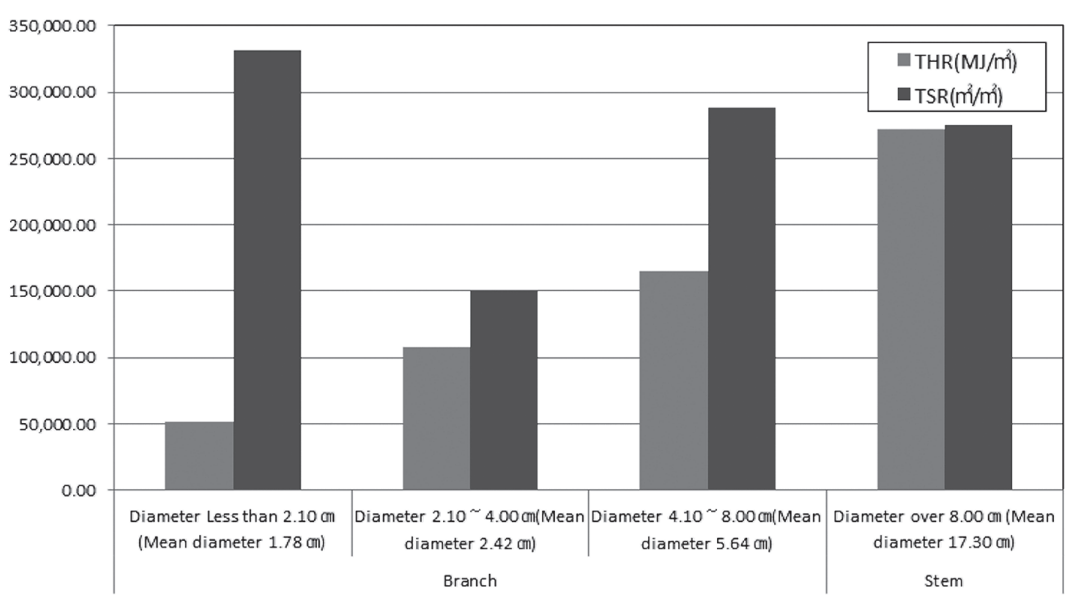

Fig. 3. Characteristics of THR and TSR of Biomass amounts by parts of Cork oaks.

than stem parts. Although early forest fire risk is low as medium-sized branches and thick branches continued burning for longer periods, those branches were more vulnerable to fire when forest fire broke out.

\section{Characteristics of fire load}

Figure 3 shows results from total heat release by parts from biomass amounts of cork oaks and total heat releases from species. Regarding total heat release by parts, branch parts with $1.76 \mathrm{~cm}$ in average was $38.7 \mathrm{~kg}$ and emitted $51,780.6 \mathrm{MJ} / \mathrm{m}^{2}$ heats. Medium-sized branches with $2.42 \mathrm{~cm}$ in average turned out $85.2 \mathrm{~kg}$ and emitted 107,522.4 MJ/m² heats. Thick branches with 5.64 $\mathrm{cm}$ in average showed $124.5 \mathrm{~kg}$ and emitted 165,087.0 MJ/ $\mathrm{m}^{2}$ heats. Therefore, branch parts with $48.4 \mathrm{~kg}$ biomass amounts emitted $324,390.0 \mathrm{MJ} / \mathrm{m}^{2}$ heats based on the assumption of $100 \%$ emission. Furthermore, $180.4 \mathrm{~kg}$ stem parts generated 2,720,432.2 MJ/m² heats. Stem 
Table 7. Analysis of Heating Value by Cork Oaks Parts

\begin{tabular}{|c|c|c|c|c|c|}
\hline \multicolumn{2}{|r|}{ Cork oak } & \multicolumn{2}{|c|}{ Weight (kg) } & \multirow{2}{*}{$\begin{array}{c}\begin{array}{c}\text { Total heating } \\
\text { value }\left(\mathrm{MJ} / \mathrm{m}^{2}\right)\end{array} \\
66.9\end{array}$} & \multirow{2}{*}{$\begin{array}{c}\begin{array}{c}\text { Total smoke value } \\
\left(\mathrm{m}^{2} / \mathrm{m}^{2}\right)\end{array} \\
427.5\end{array}$} \\
\hline \multirow{6}{*}{ Branch } & \multirow[b]{2}{*}{$\begin{array}{l}\text { Twig(Mean } \\
\text { diameter } 1.76 \mathrm{~cm} \text { ) }\end{array}$} & Burning weight & 0.05 & & \\
\hline & & $\begin{array}{l}\text { Biomass } \\
\text { amounts }\end{array}$ & 38.7 & $51,780.6$ & $330,885.0$ \\
\hline & \multirow{2}{*}{$\begin{array}{l}\text { Medium-sized } \\
\text { branch(Mean } \\
\text { diameter } 2.42 \mathrm{~cm} \text { ) }\end{array}$} & Burning weight & 0.05 & 63.1 & 87.8 \\
\hline & & $\begin{array}{l}\text { Biomass } \\
\text { amounts }\end{array}$ & 85.2 & $107,522.4$ & $149,611.2$ \\
\hline & \multirow[b]{2}{*}{$\begin{array}{l}\text { Thick(Mean } \\
\text { diameter } 5.64 \mathrm{~cm} \text { ) }\end{array}$} & Burning weight & 50 & 66.3 & 115.8 \\
\hline & & $\begin{array}{l}\text { Biomass } \\
\text { amounts }\end{array}$ & 124.5 & $165,087.0$ & $288,342.0$ \\
\hline \multirow{2}{*}{\multicolumn{2}{|c|}{ Stem (Mean diameter $17.30 \mathrm{~cm}$ ) }} & Burning weight & 50 & 75.4 & 76.3 \\
\hline & & $\begin{array}{l}\text { Biomass } \\
\text { amounts }\end{array}$ & 180.4 & $272,043.2$ & $275,290.4$ \\
\hline & Sum & $\begin{array}{l}\text { Total biomass } \\
\text { amounts }\end{array}$ & 428,800 & $596,433.2$ & $1,044,128.6$ \\
\hline
\end{tabular}

parts emitted 1.84 times more heats than branch parts and total heat release of cork oaks turned out 596,433.2 $\mathrm{MJ} / \mathrm{m}^{2}$. Quantitative values are shown in Table 7 . Heat release by branch parts corresponded with fire continuing time and stem parts showed highest heat releases in spite of shorter fire continuing time than thick branches. This difference is assumed to be derived from different biomass amounts and burning size. Therefore, stem parts seem to show higher fire loads due to relatively higher ignition risk and heat releases than branch parts when forest fire occurs.

\section{Fire vulnerability}

Amounts of smoke emission by parts of cork oaks were shown in Table 4 . Observing smoke release by parts, branch parts emitted $768,838.2 \mathrm{~m}^{2} / \mathrm{m}^{2}$ smoke and stem parts emitted $275,290.4 \mathrm{~m}^{2} / \mathrm{m}^{2}$ smoke. It indicated that branch parts generated 1.36 times more smokes than stem parts. Total smoke release of cork oaks emitted $1,044,128.6 \mathrm{~m}^{2} / \mathrm{m}^{2}$ smokes. Twigs that emitted relatively more total smoke releases were assumed to be influenced by incomplete burning and crown fire is assumed to be vulnerable when forest fire breaks out.

\section{CONCLUSION}

1. Regarding the characteristics of moisture content, cork oaks in April when forest fire frequently occurs were found to contain water ranging between $42.62 \%$ and $49.84 \%$. In addition, branch parts of total amounts of biomass was $248.40 \mathrm{~kg}$, accounting for 57.93 wt.\%. As stem parts turned out $180.4 \mathrm{~kg}$ and weight ratio was identified as 42.07 wt.\%, branch parts showed 8\% higher of weight ratio than stem parts.

2. Igniting temperature of cork oaks ranged between $490^{\circ} \mathrm{C}$ and $550^{\circ} \mathrm{C}$. Stem parts are likely to be fired at the beginning of burning than stem parts. As medium-sized branch and thick branch showed longer burning after ignition, early forest fire risk is low, yet more vulnerable to fire when forest fire continues.

3. In regard to the characteristics of fire load, branch parts of $248.4 \mathrm{~kg}$ biomass emitted $324,390.0 \mathrm{MJ} / \mathrm{m}^{2}$ heats and stem parts of $180.4 \mathrm{~kg}$ biomass emitted 2,720,432.2 $\mathrm{MJ} / \mathrm{m}^{2}$ heats. This indicated that branch parts emitted 1.84 times more heats than stem parts. On top of that, it was revealed that cork oaks emitted 596,433.2 MJ/m² heats.

4. Observing the characteristics of smoke releases, branch parts emitted $768,838.2 \mathrm{~m}^{2} / \mathrm{m}^{2}$ smoke and stem parts generated $275,290.4 \mathrm{~m}^{2} / \mathrm{m}^{2}$ smoke. This demonstrates that branch parts generate 1.36 times more smoke than stem parts. Total smoke release of oaks was found to emit $1,044,128.6 \mathrm{~m}^{2} / \mathrm{m}^{2}$ smoke.

5. In regard to carbon dioxide emissions of cork oaks, branch parts emitted $489.90 \mathrm{~kg}$ and stem parts released $375.37 \mathrm{~kg}$ carbon dioxide. In addition, branch parts emitted $2.20 \mathrm{~kg}$ and stem parts emitted $17.46 \mathrm{~kg}$ of carbon monoxide. This showed that total release of carbon dioxide by species turned out $865.28 \mathrm{~kg}$ and that of carbon monoxide found $39.68 \mathrm{~kg}$.

\section{AUTHOR CONTRIBUTIONS}

Y. J. PARK designed the research, experimental design and experimental supervision were conducted for experimental study. S. Y. LEE wrote an English paper, experimental supervision was carried out. and S. OHGA designed the study, supervised the research. All authors assisted in editing the manuscript and approved the final version. 


\section{ACKNOWLEDGEMENTS}

This research was supported by Basic Science Research Program through the National Research Foundation of Korea(NRF) funded by the Ministry of Education(No. 2016R1D1A1B02008374).

\section{REFERENCES}

Hong, Y. M. and G. S. Jung, "Safety Engineering Experiment", Donghwa Technology, pp. 9-11, (1992)

IPCC, "National Greenhouse Gas Inventories Programme", Good Practice Guidance for Land, (2003)

ISO $5660-1$, Reaction to fire part 1 , rate of heat release from building products (Cone Calorimeter), (2002)

Kang J. Y, S. W. Kim, Y. C. Kim, J. G. Kim, J. S. Kim, S, C. Park, Y. G.
Park, S. W. Lee, S. Y. Lee, Y. S. Lee, C. H. Lee, H. H. Lee, S. B. Jeong and J. G. Hyeon, Studies on Forest Environment Preservation, Hyangmunsa: Seoul, pp. 34-58, (2002)

Korea Forest Service, Forest Basic Statistics in 2010, pp. 1-48, (2011)

KOREA Forest Service, Forest Comprehensive Measures in Response to Climate Change: Practices by Fields, (2008).

Korea Forest Service, Recent Trend in Forest Fire Occurrence: 2001-2010, Use, Land-Use Change and Forestry, http://fire.forest.go.kr /main/index.asp. (Accessed on 2011).

Lee B. D, and J. S. Jeong, H. H. Kim, S. Y. Lee, An Analysis of Forest Fire Spreading Speed in Samcheok Forest Firest in 2006 by GIS Application, Journal of The Korean Forestry Society, Vol. 90, No. 6, pp. 781-787, (2001)

Lee S. Y, Forest Fire Preventive System in Foreign Countries, Special Cover in Preventing Forest Fires by Korea Forest Research Institute, Vol. 6, No. 4, pp. 25-33, (2004).

Yim K. G., "Forestation Theory", Hyangmoonsa, pp. 120-174, (2007). 